Bond University ePublications@bond

Sports Law eJournal

Faculty of Law

$12-2017$

\title{
Olympism and the Olympic Charter - The Potential for Women
}

Simone Pearce

University of the Sunshine Coast

Follow this and additional works at: http://epublications.bond.edu.au/slej

Part of the Law Commons

\section{Recommended Citation}

Pearce, S. (2017). Olympism and the Olympic Charter - The Potential for Women. Retrieved from http://epublications.bond.edu.au/ slej/33

This Journal Article is brought to you by the Faculty of Law at ePublications@bond. It has been accepted for inclusion in Sports Law eJournal by an authorized administrator of ePublications@bond. For more information, please contact Bond University's Repository Coordinator. 


\title{
Olympism and the Olympic Charter - The Potential for Women
}

\begin{abstract}
Extract:

The involvement of women in and around the Olympic Games has been the subject of much conjecture.The International Olympic Committee (IOC) has over many years, undertaken significant efforts to advance the position of women in and in relation to the Olympic Games. One way the IOC has sought to increase the participation of women athletes at the Olympic Games in recent times, has been to agitate for the inclusion of women from countries where representation has not occurred in the past, or has been poor.
\end{abstract}

\section{Keywords}

Olympic movement, committee, sport, society

\section{Disciplines}

Law 


\title{
OLYMPISM AND THE OLYMPIC CHARTER -THE POTENTIAL FOR WOMEN
}

\author{
SIMONE PEARCE*
}

\section{INTRODUCTION}

The involvement of women in and around the Olympic Games has been the subject of much conjecture. ${ }^{1}$ The International Olympic Committee (IOC) has over many years, undertaken significant efforts to advance the position of women in and in relation to the Olympic Games. One way the IOC has sought to increase the participation of women athletes at the Olympic Games in recent times, has been to agitate for the inclusion of women from countries where representation has not occurred in the past, or has been poor.

The IOC is the entity responsible for the Olympic Movement. ${ }^{2}$ The IOC conducts its affairs pursuant to the Olympic Charter, a document setting out Fundamental Principles of Olympism, said to 'govern the organisation, action and operation of the Olympic Movement'. ${ }^{3}$ The Olympic Charter contains a number of assertions relating to human rights and discrimination. ${ }^{4}$ These

* Lecturer in Law, University of the Sunshine Coast.

1 See, eg, Linda Sheryl Greene, 'Mirror, Mirror on the Wall-Gender, Olympic Competition and Persistence of the Feminine Ideal' (2016) 31(2) Wisconsin Journal of Law, Gender and Society; see also Madeline Pape, 'Women in the Olympic and Paralympic Movements: Framing, Bureaucracy, and Advocacy in Periods of Change, Final Report for the IOC Olympic Studies Centre, March 2017, University of Wisconsin-Madison, United States of America; See also $<$ http://www.laici.va/content/laici/en/sezioni/donna/notizie/le-donne-alle-

olimpiadi.html>; See also Peter Donnelly, Michele K. Donnelly, The London 2012 Olympics: A Gender Equality Audit, Centre for sports Policy Studies, March 2013, Loughborough University, International Olympic Committee and Centre for Olympic Studies \& Research, Loughborough University, April 2010, Gender Equity and Leadership in Olympic Bodies, Women, Leadership and the Olympic Movement 2010; $<$ http://assets.sportanddev.org/downloads/the_london_2012_olympics_a_gender_equality _audit.pdf $>$;

https://stillmed.olympic.org/Documents/Reference_documents_Factsheets/Women_in_Ol ympic_Movement.pdf; Helen Jefferson Lenskyj, 'Women and the Olympics: Research, Activism, and an Alternative View' (2010) Gender, Sport and the Olympics 9, 2: ; Patrick B Kraemer, 'Women athletes are still put in second place at the Olympics - it's time to sprint towards equality', The Conversation, 11 August $2016<$ http://theconversation.com/womenathletes-are-still-put-in-second-place-at-the-olympics-its-time-to-sprint-towards-equality63296>.

2 See Jean-Loup Chappelet and Brenda Kubler-Mabbott, The International Olympic Committee \& the Olympic System the Governance of World Sport (Routledge Taylor \& Francis Group, 2008) xxi.

3 The Olympic Charter, in force as of 2 August 2015.

4 The Olympic Charter, in force as of 2 August 2015, 13, 18, 19. 
assertions encompass the treatment of women. The Olympic Charter appears to assert the IOC and the Olympic Movement have influence for the treatment of women in sport and in society-beyond just the Olympic Games. This article examines the potential of the Olympic Charter and Olympic Movement regarding influencing the treatment of women, more broadly than just in the Olympic Games, but in sport and in society.

The human rights of women, in their treatment in some sectors of society, are violated when they do not have the same rights as men. ${ }^{5}$ Arguably, one of the roles of the IOC is to have a positive influence on the human rights of women. ${ }^{6}$ Traditionally the United Nations has been active in trying to influence human rights violations and/ or discrimination against women. The IOC and the United Nations have developed a relationship that is intended to capitalise on the 'power' of the IOC and the Olympic Games to contribute to the United Nations efforts regarding various matters. ${ }^{7}$ One of those efforts is the treatment of women throughout the world.

This article asks whether the human rights of women around the world can be improved by the efforts of the IOC to improve the position of women in and in relation to the Olympic Games, and the IOC using the goals in the Olympic Charter to have influence beyond the Olympic Games.

This article has four Parts. Part one briefly explains the potential basis for the argument that the IOC has potential to be of influence in the treatment of women, based on the Olympic Charter terms and the concept of the Olympic Movement. ${ }^{8}$ Part two identifies the issues regarding women's involvement in the Olympic Movement as athletes and in governance, and the progress of the Olympic Agenda 2020 efforts for the improvement of the involvement of women in the Olympic Games and in sport. ${ }^{9}$ Part three discusses the relationship between participation at the Olympic Games of women and the human rights of women, in particular, that the mandatory inclusion of women at the Olympic Games is a questionable approach to achieving the aims in the Olympic Charter of non-discrimination, preservation of human dignity and the access to

5 See, eg, <http://www.ohchr.org/EN/Issues/Women/WRGS/Pages/WRGSIndex.aspx>.

6 See, eg, The International Olympic Committee/ promote Olympism in Society/ Collaboration with the UN <https://www.olympic.org/cooperation-with-the-un>.

7 See <https://www.olympic.org/news/sport-lauded-by-un-for-its-power-to-spur-socialchange $>$.

8 The United Nations is an international organization founded in 1945. It is currently made up of 193 Member States. The mission and work of the United Nations are guided by the purposes and principles contained in its founding Charter <http://www.un.org/en/aboutun $/>$.

9 Olympic Agenda 2020, 20+20 recommendations, the outcome of the 127th IOC session on the 8th and 9th December 2014, after significant consultation and working group discussions to reform the delivery of the Olympic Games <https://www.olympic.org/olympic-agenda$2020>$. 
freedoms. This article concludes in Part four by considering how the Olympic Movement and IOC could have an influence on the human rights of women. In particular this article argues that the IOC explicitly mandates gender equity in the Olympic Movement.

\section{The Olympic MOVement and THe Olympic Charter - POWER AND INFLUENCE.}

The Olympic Games attracts significant attention worldwide, primarily as it is considered the pinnacle of sporting events. The Olympic Movement and IOC have arguably developed a level of respect and resulting power to effect change in social attitude and behaviour. For example, South Africa was excluded from the Games of 1960 at Tokyo on the basis of apartheid policy in the country. It was only a change of political regime that brought South Africa back into the fold at the 1992 Barcelona Olympic Games. ${ }^{10}$ Rhodesia was excluded from the 1972 Munich Olympic Games because of their racist regime. ${ }^{11}$ A United Nations "Security Council" resolution threatened participation of Yugoslavia at the 1992 Barcelona Olympic Games on human rights issues. ${ }^{12}$ The most prominent influence in recent time has been the work and influence in the use of doping techniques in and around sporting contests. The IOC has developed the World Anti -Doping Association, the World Anti-Doping Code and an agreement with the United Nations regarding the regulation of doping in sport. 13 The IOC banned Russian athletes from the Rio Olympic Games because of the Russian state's regime of systematic doping of athletes. ${ }^{14}$ The Olympic Charter requires compliance with the WADC and the requirements of the WADA to be recognised by the IOC and permitted to participate in the

10 See Chappelet andKubler-Mabbott, above n 2, xxi.

11 Ibid. Note, Rhodesia became Zimbabwe, an independent African nation in 1980. See also, Maureen Smith, "Examining "The Rhodesian Affair:" The IOC and African Politics in the 1970s' in 'Pathways: Critiques and Discourse in Olympic Research Ninth International Symposium for Olympic Research', Editors Robert K. Barney Michael K. Heine Kevin B. Wamsley Gordon H. MacDonald, Capital university of Physical Education Beijing, PRC August 5-7; $2008<$ http://library.la84.org/SportsLibrary/ISOR/isor2008o.pdf>.

12 Chappelet and Kubler-Mabbott, above n 2, xx.

13 IOC developed a relationship with the United Nations and has resulted in UNESCO International Convention against Doping in Sport and International Forum on Sport, Peace and Development. <http://portal.unesco.org/en/ev.php-

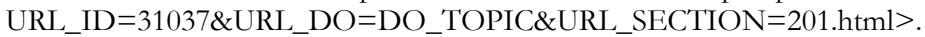

14 See Decision of the IOC Executive Board concerning the participation of Russian athletes in the Olympic Games Rio 2016 <https://www.olympic.org/news/decision-of-the-iocexecutive-board-concerning-the-participation-of-russian-athletes-in-the-olympic-games-rio2016>. The IOC stopped short of banning the entire Russian team, and the ban in this instance could be said to be on the grounds of eliminating the risks of 'cheating' going undetected. However, the ban was an example of the strength of the IOC in the movement against the use of drugs in sport. 
Olympic Games. ${ }^{15}$ The development of the WADA and the WADC has been so significant that it goes beyond the Olympic Games and now influences the majority of sports and is supported by the United Nations. ${ }^{16}$ After collaboration with the IOC, the United Nations (UN) implemented the International Convention against Doping in Sport 2005. ${ }^{17}$

The IOC has worked with the UN and has Permanent Observer status at the UN General Assembly, which is unique for an 'independent' sporting organisation. ${ }^{18}$ The IOC has gained recognition by way of UN resolutions and recognition, including Memoranda of Understanding to attempt to have an influence on social change. ${ }^{19}$ The IOC and the UN claim to have collaborated to have sport a means to 'promote internationally agreed development goals', established by the UN 2030 Agenda'. ${ }^{20}$ One of the sustainable development goals relates to women namely to; 'Achieve gender equality and empower all women and girls (SDG 5)'. ${ }^{21}$

Any influence the IOC may have over social issues is founded in the Olympic Charter, because that is the document that sets out the rules for the conduct of the Olympic Games and includes 'Fundamental Principles' intended to exert influence in relation to society. For example:

1. Olympism is a philosophy of life, exalting and combining in a balanced whole the qualities of body, will and mind. Blending sport with culture and education, Olympism seeks to create a way of life based on the joy of effort, the educational value of good example, social responsibility and respect for universal fundamental ethical principles.

2. The goal of Olympism is to place sport at the service of the harmonious development of humankind, with a view to promoting a peaceful society concerned with the preservation of human dignity.....

And

15 The Olympic Charter, in force as of 2 August 2015, Rules 2.3.4, 25, 40, 43, 44,45, By law to rule 44 and by law to rule 45,59 .

16 See The United Nations International Convention against Doping in Sport 2005, entered into force on 1 February 2007; see also

$<$ http://www.unesco.org/new/en/social-and-human-sciences/themes/anti-doping/unescoand-wada/ $>$.

17 See<http://portal.unesco.org/en/ev.php-

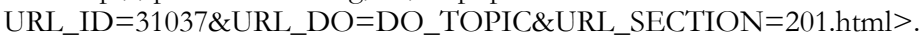

18 This position is only meant for non-member nation states and the intergovernmental organizations. See, eg, <https://thesocietypages.org/engagingsports/2017/05/15/the-iocand-the-united-nations-strategic-and-strange-bedfellows $/>$.

19 Ibid; See also <http://www.un.org/apps/news/story.asp?NewsID=47671\#.WWVzYSGOUk>.

20 See $<$ https://www.olympic.org/cooperation-with-the-un>.

21 Ibid. 
3. The enjoyment of the rights and freedoms set forth in this Olympic Charter shall be secured without discrimination of any kind, such as race, colour, sex, sexual orientation, language, religion, political or other opinion, national or social origin, property, birth or other status. ${ }^{22}$

Each of those Fundamental Principles is relevant to the treatment of women. The Olympic Charter also sets out the 'Mission and Role' of the IOC. ${ }^{23}$ This includes assertions relevant to the treatment of women:

1. to act against any form of discrimination affecting the Olympic Movement;

2. to encourage and support the promotion of women in sport at all levels and in all structures with a view to implementing the principle of equality of men and women;

3. to encourage and support the development of sport for all;

4. to encourage and support initiatives blending sport with culture and education. ${ }^{24}$

The Olympic Charter also provides for the IOC to 'recognise' National Olympic Committees' (NOC'S) of countries and International Federations (IF's) that control sports. ${ }^{25}$ Each of the NOC's and IF's must comply with the Olympic Charter. ${ }^{26}$ The Olympic Charter contains 'Mission and Roles 'for the NOC's and IF's. ${ }^{27}$ IF's are required to ' contribute to the achievement of the goals set out in the Olympic Charter'; ${ }^{28}$ the NOC's to 'develop, promote and protect the Olympic Movement in their respective countries, in accordance with the Olympic Charter' 29 and they are to ensure the observance of the Olympic Charter in their countries'. ${ }^{30}$

A question posed by this article is whether the requirements to comply with the Olympic Charter and the leverage being fostered by the relationship with the United Nations, translates to the ability of the IOC to influence the treatment of women beyond the Olympic Games and Olympic Movement and to the human rights treatment of women in society. To date, the relationship between the IOC and UN has not translated to the improvement in the treatment of

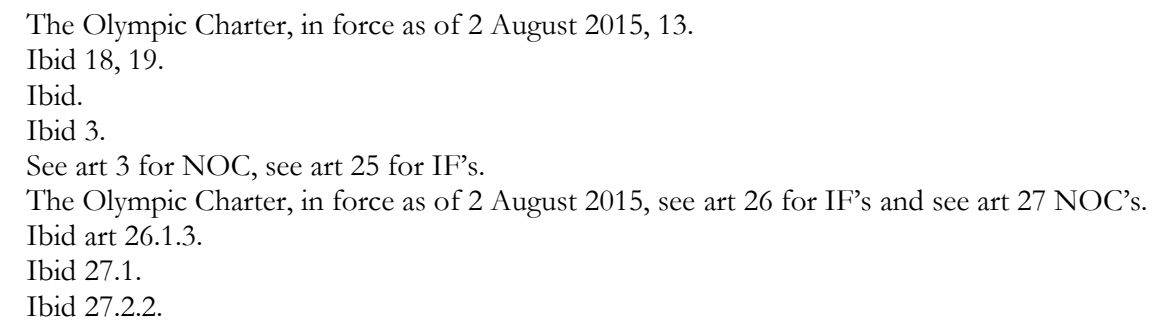


women in nations such as Saudi Arabia. ${ }^{31}$ There is an opportunity to leverage the relationship between the UN and the IOC to make better advances for the human rights of women. This article considers the role of the IOC to influence the treatment of women beyond the Olympic Games, by direct influence, its influence, if any, over NOC's and IF's as set out in the Olympic Charter, and in the relationship with the UN. Relevant to the potential influence the IOC has over the treatment of women beyond the Olympic Games is whether the IOC complies with its own Charter in delivery of the Olympic Games and the Olympic Movement. As at 2016, the IOC does not give effect to the terms of the Olympic Charter in relation to women in and around the Olympic Games and Movement.

\section{THE IOC'S TREATMENT OF WOMEN IN THE OLYMPIC MOVEMENT}

Historically, women have been treated differently from men in their representation in events at the Olympic Games and in the representation of women in roles in all levels of the Olympic Movement. The issues surrounding the number of women in both athletic and other roles in the Olympic Movement are significant for two reasons; firstly because many women seek to have the same opportunities as men to participate in the Olympic Movement, and secondly, because the IOC includes Fundamental Principles and Missions and Roles in the Olympic Charter to provide women the opportunity of equality with men. ${ }^{32}$

Throughout the time of modern Olympic Games, women have been excluded from events available to men. ${ }^{33}$ There have been various efforts to have women included in the Olympic Games in a manner aligned to the men's inclusion, such as from 1928 until 1964 when women were excluded from the 800 metre track event, to the eventual inclusion in ski jumping in $2014 .{ }^{34}$ Notwithstanding

31 See, eg, Amanda Erickson, 'Believe it or not, Saudi Arabia was elected to the U.N. women's rights commission', The Washington Post (online) 3 May 2017 <https://www.washingtonpost.com/news/worldviews/wp/2017/05/03/saudi-arabia-

where-women-arent-allowed-to-drive-was-just-elected-to-the-u-n-womens-rights-

commission/?utm_term $=.4 \mathrm{~b} 5733039 \mathrm{eb} 9>$; note the UN was widely criticised for admitting Saudi Arabia to the UN Women's Rights Commission.

32 The Olympic Charter, in force as of 2 August 2015,22-4.

33 See Anita DeFrantz, Chairwoman, 'IOC Working Group on Women and Sport, The changing role of women in the Olympic Games'; Madeline Pape, 'Women in the Olympic and Paralympic Movements: Framing, Bureaucracy, and Advocacy in Periods of Change', Final Report for the IOC Olympic Studies Centre, March 2017, University of WisconsinMadison, United States of America; Sarah Teetzel, Equality, 'Equity, and Inclusion: Issues in Women and Transgendered Athletes' Participation at the Olympics, $<$ http://library.la84.org/SportsLibrary/ISOR/ISOR2006ae.pdf >.

34 See Roger Robinson, 'Eleven Wretched women', Running Times Magazine May 2012; See also 'Why Women can't Ski Jump in the Olympics' Winter Olympics Games TIME; 
the efforts and attention to the improvement of the position of women in the Olympic Games and Movement, targets and goals have not been achieved. As at 2016, the numbers of women participating in the Olympic Games was less than men, notwithstanding that two sports are for women only-- rhythmic gymnastics and synchronised swimming. ${ }^{35}$ Many events at the Olympic Games are offered on differing basis for men and women. ${ }^{36}$ Participation of women at the Olympic Games is also at times affected by the actual event being offered as well as the way in which the event is offered. ${ }^{37}$ The statistics regarding the differences in treatment for women from men at the Olympic Games suggest that women are not treated in a way that provides them the opportunities in the context of the Olympic Movement and the Fundamental Principle of eliminating discrimination. ${ }^{38}$ The improvement of opportunities for women to participate in the Olympic Games is on ongoing process, and the subject of significant efforts by the IOC.

In December 2014, the IOC World Conference settled on the Olympic Agenda 2020 (Agenda 2020), setting the program for the reform and improvement of the Olympic Movement over the following 6 years. Olympic Agenda 2020 includes some recommendations regarding gender issues in the Olympic Games and Olympic Movement. ${ }^{39}$ Referred to as individual pieces of a jigsaw puzzle' the recommendations strive to manage the size of the Olympic Games, balanced with accommodating the sports and the events seeking to be included, and an equal division of opportunities to compete between men and women. ${ }^{40}$ There are challenges in implementing the Agenda 2020 recommendation of achieving equal numbers of men and women at the Olympic Games, when

<http://content.time.com/time/specials/packages/article/0,28804,1963484_1963490_1963 447,00.html?.

35 See Peter Donnelly, Michele K. Donnelly, The London 2012 Olympics: A Gender Equality Audit, Centre for sports Policy Studies, March 2013, Loughborough University, International Olympic Committee and Centre for Olympic Studies \& Research, Loughborough University, April 2010, Gender Equity and Leadership in Olympic Bodies, Women, Leadership and the Olympic Movement 2010; $<$ http://assets.sportanddev.org/downloads/the_london_2012_olympics_a_gender_equality _audit.pdf $>$.

36 Ibid.

37 Ibid. Note that the rules in the various sports of the Olympics, is left to the International Federations and they are accordingly responsible for the rules relating to the treatment women within their respective sports. See also, 'Women in sport, Promotion of women in sport'; Background <https://www.olympic.org/women-in-sport/background>.

38 Donnelly and Donnelly, above $\mathrm{n} 35$.

39 Olympic Agenda 2020, 20+20 recommendations, the outcome of the $127^{\text {th }}$ IOC session on the $8^{\text {th }}$ and 9th December 2014, after significant consultation and working group discussions to reform the delivery of the Olympic Games.

40 Ibid 1, Recommendations 10-11. 
there are sports that do not involve significant participation by women and there are events that are for women alone. ${ }^{41}$

Agenda 2020 came after numerous efforts by the IOC regarding the increase in the representation of women in the Olympic Movement, not only in athletic roles, but in governance, administration and coaching roles throughout the Olympic Movement. ${ }^{42}$ Historically, the IOC has set targets for the inclusion of percentages of women in governance roles within the Olympic Movement. ${ }^{43}$ The inclusion of greater numbers of women in governance and other roles in the Olympic Movement is recognised by the IOC as being appropriate and necessary to comply with the Olympic Charter and Olympic Movement. ${ }^{4}$ The Women in Sports Commission of the IOC has worked and advocated for the involvement of women at various levels of sport. ${ }^{45}$ 'Women and Sport Awards' celebrate the efforts of countries, NOC's and IFs to promote women. ${ }^{46}$ The Los Angeles Declaration in 2012 promoted the inclusion of women in governance, management and leadership in sport, and declared the need for greater education of the importance of the role of women in sport. ${ }^{47}$ Since 2012, the IOC has adopted the Brighton Plus Helsinki 2014 Declaration which includes numerous calls to action of sporting bodies and government agencies

41 Greco Roman, 'Wrestling has very few female competitors, and Synchronised Swimming and Rhythmic Gymnastics are for women only at the Olympic Games'.

42 See < https://www.olympic.org/women-in-sport/background/statistics>.

43 Recommendations from the $2^{\text {nd }}$ IOC World Conference on Women and Sport Paris 2000 adopted by the IOC, that the IOC, NOCs, IFs, National Federations and sporting bodies belonging to the Olympic Movement set the objective of reserving at least 20 per cent of the decision making positions for women by the end of 2005. That was not achieved. A goal of achieving 10 per cent of women in decision-making roles by end 2000 was met by 61 per cent of NOCs and 52 per cent of IFs. See the IOC, Fact sheet -Women in the Olympics Movement (updated January2016). $<$ http://www.olympic.org/Documents/Reference_documents_Factsheets/Women_in_Oly mpic_Movement.pdf $>$.

44 The Los Angeles Declaration, 5th IOC World Conference on Women and Sport, 16-18 February 2012, Los Angeles, California. $<$ http://www.olympic.org/Documents/Commissions_PDFfiles/women_and_sport/LosAngeles-Declaration-2012.pdf $>$; see also, $<$ http://www.olympic.org/Documents/Commissions_PDFfiles/women_and_sport/report _5th_conference_women_and_sport_EN.pdf $>$.

45 See <http://www.olympic.org/women-in-sport-commission>. The Commission was renamed from the 'Women and sport Commission' in the outcomes of the Olympic Agenda 2020, 20+20 Recommendations; See also <https://www.olympic.org/women-insport/advocacy>.

46 See <http://www.olympic.org/women-in-sport-commission?tab=advocacy $>$.

47 The Los Angeles Declaration, 5th IOC World Conference on Women and Sport, 16-18 February 2012, Los Angeles, California. $<$ http://www.olympic.org/Documents/Commissions_PDFfiles/women_and_sport/LosAngeles-Declaration-2012.pdf>; $<$ http://www.olympic.org/Documents/Commissions_PDFfiles/women_and_sport/report _5th_conference_women_and_sport_EN.pdf>. 
to prioritise the position and involvement of women in sport. ${ }^{48}$ Agenda 2020 recommendation 27 provides for compliance with the Basic Universal Principles of Good Governance of the Olympic and Sports Movement, ${ }^{49}$ advocated by the IOC Ethics Commission, providing for member representation and minority representation, particularly women. ${ }^{50}$ There is however no new 'target' in the Agenda 2020 recommendations for the elevation of women to governance roles in any level of the Olympic Movement. ${ }^{51}$ The statistics surrounding women's roles in the 'non-athlete' areas of the various sports are alarmingly bleak. Women account for 24 of the 106 members of the IOC:52 and the numbers of women in governance positions in NOC's and IF's fall below the targets set by the IOC for women in governance roles in the Olympic Movement. ${ }^{53}$

The 'IF Women in Leadership Forum' in 2016 resulted in a ten-point action plan that is to establish a 'Gender Equity Working Group' and revisit previous commissioned reports. ${ }^{54}$ The outcomes of the Forum are reminiscent of previous efforts that have not been successful in changing significantly the treatment of women in relation to and at the Olympic Games. Consequent upon the Agenda 2020 recommendations the IOC announced in March 2017 a 'major review project regarding gender equality in the Olympic Movement'. ${ }^{55}$ There is no guidance from the IOC about what that review will involve, or specifics on what it seeks to achieve.

The progress of the inclusion of women at all levels of the Olympic Movement has been and continues to be slow, despite the IOC's attention to the issue, and despite the terms of the Olympic Charter. The reasons for the failure of the IOC to comply with the Olympic Charter in relation to women are not simple.

48 See $<$ https://iwg--gti-org-

bin.directo.fi/@Bin/ba1a91ec9059d782527c84ded181e6fd/1500254533/application/pdf/37 $3320 /$ Helsinki $\% 20$ calls $\% 20$ the $\% 20$ world $\% 20$ of $\% 20$ sport $\% 20$ to $\% 20$ LEAD $\% 20$ THE $\% 20$ C

HANGE,\%20BE\%20THE\%20CHANGE.pdf?.

49 The Olympic Agenda 2020, 20+20 recommendations, Recommendation 27.

50 Basic Universal Principles of Good Governance of the Olympic and Sports Movement, art. 2.4.

51 Although a new 'IOC Members Election Commission' charged with a criteria that will consider gender balance see The Olympic Agenda 2020, 20+20 recommendations, Recommendation 38.

52 The total number of members can be 115. See the Olympic Charter as in force 2 August 2015, Art. 16. See also Sharp Center for Women \& Girls, Women's Sports Foundation 'Women in the Olympic and Paralympic Games, An analysis of Participation and leadership opportunities, Research Report, April 2013; <http://idrottsforum.org/wpcontent/uploads/2013/04/Olympic_Report_2012_FINAL-4.11.13 .pdf>.

53 IOC, Fact sheet -Women in the Olympics Movement - updated January 2016.

54 The Forum conducted in Lausanne from 7-9 March 2016, was hosted by the IOC and the Association of Summer Olympic International Federations

$<$ http://www.olympic.org/news/ first-if-women-in-leadership-forum-ends-in-call-toaction $/ 248828>$.

55 See <https://www.olympic.org/news/ioc-launches-bold-initiative-on-gender-equality $>$. 
However, the reasons for the failure to comply with the Olympic Charter in relation to women is interrelated with issues that are beyond the Olympic Games and Olympic Movement, such as the culture and religion in various countries who seek to participate in the Olympic Games, that sees women treated in a manner that is discriminatory and or offends their human rights. Ironically, it may be the that the IOC has the opportunity in relation to these countries to influence the treatment of women in society, if the IOC were to take a stronger position and comply with the Olympic Charter within the Olympic Games and Movement. The next part of this article explains the opportunity the IOC has to influence the treatment of women beyond the Olympic Movement.

\section{THE RELATIONSHIP BETWEEN THE DISCRIMINATION OF WOMEN, HUMAN RIGHTS AND SPORT AND THE OLYMPIC MOVEMENT}

The 2012 London Olympics were touted as the 'Women's Games'.56 It was claimed that for the first time ever, at least one woman competed for every country that attended and women competed in every sporting discipline. ${ }^{57} \mathrm{It}$ was reported that the IOC did exert pressure on these countries to meet the achievement of a women participant from every country, particularly urging Saudi Arabia to send female athletes, or risk not being permitted to send their male athletes. ${ }^{58}$ These achievements were understandably celebrated as a success for the IOC and women. However, the performances of some of the

56 See, eg, Robin Scott-Elliot,' London 2012 Olympics: The Women's Games', Independent, 26 July, 2012; see also <http://www.independent.co.uk/sport/olympics/news/london-2012olympics-the-womens-games-7976835.html>; Sarah Brown, London 2012: The Women's Olympics? <http://edition.cnn.com/2012/08/10/sport/london-olympics-women/>; Emily Dugan, Sunday Ladies first: Why 2012 is the Women's Games; Independent, 8 July 2012 $<$ http://www.independent.co.uk/sport/olympics/ladies-first-why-2012-is-the-womensgames-7920011.html>.

57 Note that the media claims were incorrect and, Barbados, Nauru and the Federation of Saint Kitts and Nevis did not send any women, although they have sent women in the past. See Sharp Center for Women \& Girls, Women's Sports Foundation 'Women in the Olympic and Paralympic Games, An analysis of Participation and leadership opportunities, Research Report, April $2013 \quad<$ http://idrottsforum.org/wpcontent/uploads/2013/04/Olympic_Report_2012_FINAL-4.11.13.pdf>. Note also, boxing for women was also introduced as a discipline at the Olympics for the first time. The participation in sporting disciplines was subject to the availability of the events in each discipline which is dealt with later in this paper.

58 Human Rights Watch, 17 September 2014, 'Saudi Arabia: No Women on Asian Games Team', Olympic Committee Says Women to Compete in 2016 Olympics. <https://www.hrw.org/news/2014/09/17/saudi-arabia-no-women-asian-games-team>; Human Rights Watch, “Steps of the Devil”, Denial of Women's and Girls' Rights to Sport in Saudi Arabia February 15, 2012; https://www.hrw.org/report/2012/02/15/stepsdevil/denial-womens-and-girls-rights-sport-saudi-arabia. 
women who were included in the 2012 Olympic Games were well below that of other competitors and Olympic standards; for example16 year old Saudi Arabian Shaherkani in the Judo who was a blue belt whilst other competitors were black belts; Kohistani from Afghanistan competed in the 100 metres, with a time of more than 14 seconds; Al Malki, Qatar's first female Olympian stopped after about 15 metres, famously photographed sitting on the track in her modest attire; ${ }^{9}$ Somalian runner Zamzam Mohamed Farah in the women's $400 \mathrm{~m}$ was almost 30 seconds behind the winner and 25 seconds behind the second last place getter in her heat; 19 year old Maziah Mahusin the first women to represent Brunei at the Olympics, ran a time in the 400 metres that would not qualify her for a national final in many countries. The inclusions of women from Qatar, Iran, Afghanistan, Brunei, and Saudi Arabia at the Olympic Games in 2012 were most celebrated as examples that their countries would and could permit and facilitate them to attend at the Olympic Games and that the IOC is moving towards achieving female participation equal to men's. However, the attention drawn to these women by their attendances highlighted their lack of previous opportunity and experience. ${ }^{60}$ The women representing these countries would not and could not have qualified to attend the Olympic Games by virtue of the qualifying times required. The women were eligible to compete by virtue of the 'universality principle'61 which is used to permit the entry of athletes who will not otherwise qualify, to promote opportunity at the Olympic Games in accordance with the Fundamental Principles. ${ }^{62}$

Additionally, notwithstanding the celebration of inclusion for women in the Olympic Games, there are reports of terrible circumstances for some of the women who represented their country at the 2012 Olympic Games. Shaherkani was reportedly barbed by the country's clergy, labelling her the 'Prostitute of the Olympics', and her family suffered racial abuse, with many claiming she did not represent their country. ${ }^{63}$ The Afghani female sprinter was heckled at training,

59 See Jeré Longman and Mary Pilon, Saudi Arabia May Include Women on Its Olympic Team, $\begin{array}{lllll}\text { The New } & \text { York } & \text { Times } & \text { March } & 20\end{array}$ <http://www.nytimes.com/2012/08/04/sports/olympics/for-women-from-qatar-saudiarabia-and-brunei-a-simple-triumph.html $>$.

60 See, eg, <http://www.dailymail.co.uk/news/article-2183262/Olympics-2012-The-Muslimwomen-overcame-odds-make-London.html>.

61 The attitude implemented by the IOC to permit an athlete to be admitted by a country if they are the one female or male athlete being sent by the country, or they are admitted to improve the representation of the country at the Olympics, in accordance with the fundamental principles of The Olympic Charter that the practice of sport is a human right, and that the Olympic Games is all inclusive.

62 The Olympic Charter as in force at 2 August 2015. Note that previous versions of The Olympic Charter have differing 'Fundamental Principles'.

63 Adam Shergold, 'Mail online' The Muslim Women who overcame the odds and the prejudice to make history today on the Olympic stage. 3 August 2012<http://www.dailymail.co.uk/news/article-2183262/Olympics-2012-The-Muslimwomen-overcame-odds-make-London.html $>$. 
and that was after a male cab driver had refused take her there. ${ }^{64}$ Saudi Arabia does not permit women to play sport and girls are not permitted or provided an opportunity to play sport at school. ${ }^{65}$ Women in Saudi Arabia are not permitted to use stadia of facilities to train, as they are not permitted to be seen by men; 66 laws prevent women appearing in public, provision of access to sporting facilities, the need to have a male chaperone, and clothing that requires being covered from head to toe. ${ }^{67}$ Since the 2012 Olympic Games, Saudi Arabia failed to send any women to the 2014 Asian Games. ${ }^{68}$ Olympic chief Prince Abdullah bin Mosad bin Abdlaziz asserted that Saudi Arabia did not have women who were 'ready' and would have qualified for the Asian Games, and that they were training women to compete in equestrian, fencing, shooting and archery, as they were Olympic contests that are 'accepted culturally and religiously in Saudi Arabia'.69 This did not address the two issues: first that there are insufficient women encouraged or permitted to participate in sport for them to become sufficiently experienced; and secondly, that women have dictated to them the sport they participate in.

The inclusion of women from 'every country' in the 2012 London Olympic Games was demonstrative of gains for the inclusion of women within the Olympic Movement. However, the inclusion of women on a token or contrived basis does not have the effect of improving the involvement of women in sport in these countries. ${ }^{70}$ This is in part because the requirement by the IOC to include women on the basis of 'non-discrimination' and the equitable treatment

64 Adam Shergold, 'The Muslim Women who overcame the odds and the prejudice to make history today on the Olympic' The Mail (online) 3 August 2012 $<$ http://www.dailymail.co.uk/news/article-2183262/Olympics-2012-The-Muslim-womenovercame-odds-make-London.html $>$.

65 See e,g, <https://qz.com/752289/even-as-saudi-female-olympians-compete-women-facediscrimination-back-home/>; $\quad<$ https://www.hrw.org/news/2016/08/04/saudi-arabiawomen-are-changing-game $>;<$ https://www.hrw.org/report/2012/02/15/steps$\mathrm{devil} /$ denial-womens-and-girls-rights-sport-saudi-arabia $>$.

66 Women are not permitted to attend at stadia to view sports events. The progress to improve the rights of women to have access to these facilities is improving very slowly. Women have recently and on a case by case basis been permitted entry to stadia. See James M. Doresy, 'Women's rights on sporting put Saudi Arabia, Iran on defensive' Hurriyet Daily News 27 October2014<http://www.hurriyetdailynews.com/womens\%ADrights\%ADon\%ADsportin

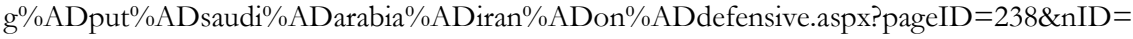
73476\&NewsCatID=364>.

67 Human Rights Watch, "Steps of the Devil", Denial of Women's and Girls' Rights to Sport in Saudi Arabia February 15, 2012 < https://www.hrw.org/report/2012/02/15/stepsdevil/denial-womens-and-girls-rights-sport-saudi-arabia $>$.

68 Human Rights Watch, 17 September 2014, 'Saudi Arabia: No Women on Asian Games Team', Olympic Committee Says Women to Compete in 2016 Olympics. <https://www.hrw.org/news/2014/09/17/saudi-arabia-no-women-asian-games-team>.

69 James M. Doresy, above n 66.

70 See Susan Dun, 'Role Models in the Media and Women's Sport Participation in Qatar, NIDABA' (2016) 1An interdisciplinary Journal of Middle East Studies 1, 48. 
of men and women, does not address the problems for the treatment of women within the country. Nor does the inclusion of women reflect that the country is fostering or providing opportunities for women. For example, in Rio, there were improvements in the numbers of female athletes for some countries with Saudi Arabia sending four women and Qatar sending two women. ${ }^{71}$ The women from Saudi Arabia at the Rio Olympic Games included Sarah Attar who had represented the country in 2012, who grew up in California, Cariman Abu Al-Jadail a student at Boston University, Judoka Wujud Fahmi who was trained in the United States and fencer Lubna Al-Omair who was trained in Egypt. Access to sport in Saudi Arabia is arguably part of a regime and culture that deters women from participating in sport. If women are not permitted, encouraged or facilitated to take part in sport, there will be little prospect of women seeking to represent that country at the Olympic Games. Likewise, if there are few capable female athletes competing at the Olympics or international level, there are no role models for girls to play sport. The social attitude in these countries that deters women and girls from sport is steeped in religious beliefs and traditions.

Also steeped in religious beliefs and traditions is the behavior towards women in some of these countries beyond access to sport, which is discriminatory and violates the rights provided for by the United Nations Convention for the elimination of discrimination against Women. ${ }^{72}$ For example, in Saudi Arabia, failure to provide access for girls to take part in sport at school is only one part of a society that condones arranged marriages, stoning of women for alleged adultery, domestic violence as a suitable behavior of a husband to a wife, and the value of a women's testimony as being worth half that of a man's. ${ }^{73}$ Female's access to even attend at sports in countries such as these is restricted. Ghoncheh Ghavami was imprisoned in Iran, after she tried to enter a stadium with a dozen other women, when the National men's volleyball team was playing Italy. ${ }^{74}$ She was charged with spreading propaganda against the Government. ${ }^{75}$

71 Ruth Jebet Gold in the Women's 3000 m steeplechase, and Eunice Kirwa in the Women's marathon.

72 Convention on the Elimination of Discrimination Against Women opened for signature 18 December 1979, I UNTS. Vol.1249, 13, UN Doc A/RES/34/180 (entered into force 3 September 1981); Note that United Nations Conventions are not binding. The principles outlined by them display an agreement by the signatories, of which there are many, to appropriate standards for domestic laws and the rights of all people.

73 Ida Lichter, Muslim Women Reformers: Inspiring Voices Against Oppression (Prometheus Books, 2009) 277.

74 Doresy, above n 66.

75 Saeed Kamali Dehghan, , 'British-Iranian woman jailed over volleyball game sees charges dropped, The Guardian (online) 2 April 2015 $<$ http://www.theguardian.com/world/2015/apr/02/british-iranian-goncheh-ghavami-jailedvolleyball-game-charges-dropped-iran $>$. 
Even when women do attend the Olympic Games, and perform successfully, that does not represent a society that is respecting women's human rights. For example, despite appearances of great advancement for women by the presence of significant and successful athletes from India in Rio, the statistics of discrimination and human rights violations in areas such as education, work and life display a disregard for the treatment of their women in society. ${ }^{76}$

So whilst the IOC strives for countries to send women to the Olympic Games it arguably masks a significant issue in the society of the treatment of women. ${ }^{77}$ The mandatory inclusion of women at the Olympic Games, whilst understandable as a strategy to encourage the improvement in the numbers of women competing and the status of women in sport within the country, is a questionable approach to achieving the aims in the Olympic Charter of nondiscrimination, preservation of human dignity and the access to freedoms. ${ }^{78}$ This is particularly so when the women included do not live in the country, and the programs for females in sporting activities are not influenced. The approach by the IOC to set targets or goals to achieve equal numbers of men and women at the Olympic Games and the focus on statistics to support advan ces for women fails to meet the commendable goals in the Olympic Charter and Movement for women. This article argues that the IOC does have an opportunity to take a stance to improve the position of women, not only in their access to sport, but in other areas of life where their human rights are violated.

\section{CONCLUSION}

This article argues that more can and should be done by the Olympic Movement regarding the status and treatment of women in and beyond the Olympic Games. It is important that the Olympic Games maintain its status to be credible and respected which enables the IOC to have influence because, the IOC can use the rules set out in the Olympic Charter to require that countries and organisations undertake certain conduct in exchange for recognition by the IOC and admission to the Olympic Games. The IOC does have the ability to influence conduct and behaviour as has been seen in the past when action was taken against human rights violations, and as was seen the Russian athletes opposed the ban in Rio over the countries sanctioned doping regime. ${ }^{79}$ The

76 Saumya Tewari, 'Despite Rio Olympics 2016 success, Indian women are routinely denied opportunities,' First Post 12 July 2017

$<$ http://www.firstpost.com/india/despite-rio-olympics-2016-success-indian-women-areroutinely-denied-opportunities-2971552.html>.

77 Ibid.

78 Ibid.

79 See Decision of the IOC Executive Board concerning the participation of Russian athletes in the Olympic games Rio 2016 <https://www.olympic.org/news/decision-of-the-iocexecutive-board-concerning-the-participation-of-russian-athletes-in-the-olympic-games-rio$2016>$. 
IOC can and should compel compliance with the Fundamental Principles in the Olympic Charter to deliver on the mandates set out in the Olympic Charter for women. This article argues that it is not only important for the human rights of the women in the particular countries, but it is paramount to the ongoing success of the Olympic Games. To simply allow the entry of women into the Olympic Games who have not reached a standard to be competitive, does not achieve the goals in the Olympic Charter, and arguably diminishes respect for the Olympic Movement.

The issue of influence over the treatment of women in different cultures is complex. Western and Olympic ideals cannot simply be imposed upon other cultures. It is not as simple as excluding the countries' athletes from competing at the Olympic Games. ${ }^{80}$ There is an opportunity for the IOC to ban countries with discriminatory practices and human rights violations that remain unattended. It has been done in the past for racial and other human rights violations, and it was contemplated and in part exercised against Russia for the existence of a doping regime. ${ }^{81}$ However, preventing a countries' athletes from competing at the Olympic Games unless they send female representatives does not immediately achieve the representation of women at the Olympic Games, nor does it change the opportunities for women within the country when there is no requirement for the athletes to be competitive and the opportunities are affected by strong beliefs and principles. The IOC appears to recognise the complexities in trying to influence the treatment of women by taking the position it has in influencing the inclusion of athletes under the universality principle. Yet, the effect of forcing countries to have female representatives participate in the Olympic Games in events for which they are ill equipped or prepared is questionable. The current inclusion of female athletes on the basis of the universality principle cannot be said to be successful in a goal to reduce discrimination against women, in sport or beyond. The tension between encouraging participation at the Olympic Games and excluding a country that does not facilitate the fair opportunity for women in sport poses a conundrum for the IOC. A priority for the IOC is the participation of women at the Olympic Games. Whilst such a priority is commendable, it results in token inclusion misses an opportunity to have influence over countries to provide better sporting development for their women. It also misses an opportunity to have influence beyond simply the issue of attendance at the Olympic Games and sporting development.

\footnotetext{
80 As called for in Human Rights Watch, "Steps of the Devil”, Denial of Women's and Girls' Rights to Sport in Saudi Arabia February 15, 2012; <https://www.hrw.org/report/2012/02/15/steps-devil/denial-womens-and-girls-rightssport-saudi-arabia>.

81 See Part 1 of this paper.
} 
This article argues that the IOC have an opportunity to have influence over countries to eliminate discrimination and provide appropriate opportunities for women both in sport and in society. The most significant step the IOC can take in influencing countries to include female participants in the Olympic Games and is to ensure that the IOC itself meets the Fundamental Principles and 'Missions and Roles' in the Olympic Charter in the IOC governance and the conduct of the Olympic Games. This article argues that the IOC should take overt and decisive action by way of example, and implement equal representation on the IOC, if not only for diverse contributions, but as an example. The IOC should prioritise the equal opportunity for women and men to compete for medals at an event based Olympic Games as recommended in Agenda 2020.82 The IOC can mandate equal representation for men and women on boards of the IFs or NOCs and exclude sports and countries that are noncompliant, as the ability already exists in the terms of the Olympic Charter that provides for the Missions and Roles of the NOC's and IF's. ${ }^{83}$ The IOC can also then require countries to enter female athletes who are capable of genuinely competing at the Olympic Games, in order to be permitted to send their team. The IOC takes direct and uncompromising action when it comes to compliance with the WADC, and the anti-doping requirements of WADA, with the terms for compliance included in the requirements for recognition by the IOC in the Olympic Charter. ${ }^{84}$ This article argues that the same stance can be taken where the inclusion of women in the Olympic Movement is concerned. The Olympic Charter already contains the terms necessary to influence the conduct of countries towards their women. The difficulty for the IOC is that it has limited influence over countries' treatment of women until it requires strict compliance with the Olympic Charter regarding the treatment of women - including within the various structures and events in the Olympic Movement.

The branding and the emotion that has been generated by the development of the Olympic Games have made it a desirable quantity. With that as currency there is arguably considerable ability to influence conduct of the participants. The IOC has previously used that influence to address inequities and injustices

82 Olympic Agenda 2020, 20+20 recommendations, Recommendation 11. Many Olympic sports could be adjusted to provide equal opportunity for men and women to win medals, with the introduction of events in the women's division, at times simply reflecting the events that the women compete in at the World Championships, such as canoeing, where women can enter the Women's Canadian C-1- $200 \mathrm{~m}$ or C-2 $500 \mathrm{~m}$ and various Kayak events. See http://www.canoeicf.com/world-championships.

83 Sharp Center for Women \& Girls, Women's Sports Foundation 'Women in the Olympic and Paralympic Games, An analysis of Participation and leadership opportunities, Research Report, April 2013,recommendations $47 \quad<$ http://idrottsforum.org/wpcontent/uploads/2013/04/Olympic_Report_2012_FINAL-4.11.13.pdf >.

84 The Olympic Charter, in force as of 2 August 2015, Rule 25 IF's and Rule 27 NOC's. 
throughout the world. ${ }^{85}$ While the Olympic Charter has been developed and evolved to go beyond the rules of the sporting event and to have influence over significant social issues, arguably with that ability is an obligation to influence where possible and necessary. The IOC should mandate gender equity in the Olympic Movement because it is necessary to affect the influence it seeks to have for the plights and rights of women in all sport and in society. As Anita De Frantz has said:

It is arguable that ideal governance and the ideal example the Olympics as an event can provide in it will assist those countries where the treatment of women and society is the worst. ${ }^{86}$

The Olympic Movement is intended to be a celebration and example of the best that can be, in all respects.

85 See, eg, The International Olympic Committee/ promote Olympism in Society/ Collaboration with the UN <https://www.olympic.org/cooperation-with-the-un; https://www.olympic.org/news/sport-lauded-by-un-for-its-power-to-spur-social-change>.

86 IOC latest news, Anita De Frantz, "Eliminating \& Preventing Violence Against Women \& Girls Through Sport" (3 March 2013) <https://www.olympic.org/news/eliminating-andpreventing-violence-against-women-and-girls-through-sport>. 